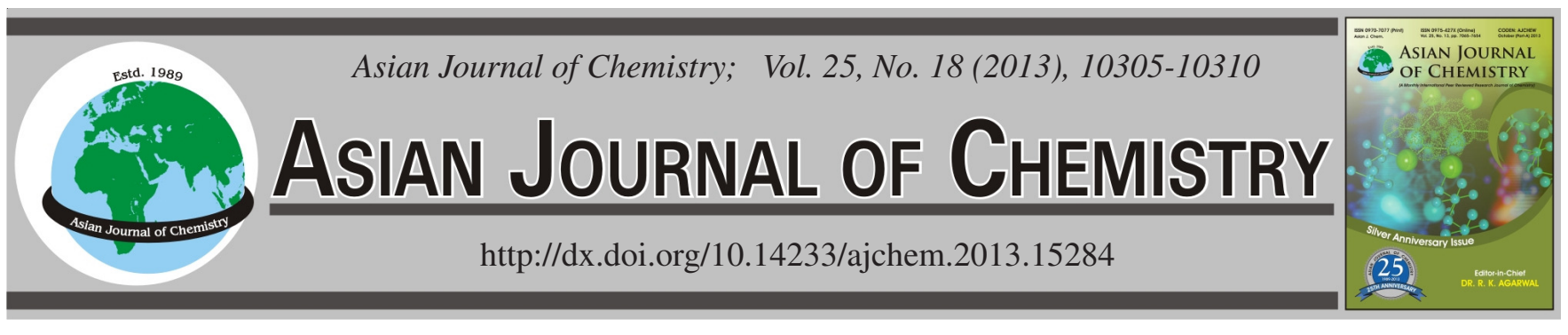

\title{
Synergistic Corrosion Inhibition of Cold Rolled Steel by Methyl Violet and Chloride Ions in Sulphuric Acid Solution
}

Lin Wang ${ }^{*}$, Fa-Chang Yang, Jie Ma, Zhi-Wen Fang, Shi-Wen Zhang, Qiang Guo, Kai-Li Lu and Yang-Xia Wang

School of Chemical Science and Technology, Yunnan University, Kunming 650091, Yunnan Province, P.R. China

*Corresponding author: Tel/Fax: +86 871 65033679; E-mail: wanglin@ynu.edu.cn; wanglin2812@163.com

(Received: 6 February 2013;

Accepted: 14 November 2013)

AJC-14389

\begin{abstract}
The corrosion inhibition of cold rolled steel in sulphuric acid solution by methyl violet in the absence and presence of chloride ion has been studied. The adsorption of methyl violet on the steel surface is found to obey the Langmuir adsorption isotherm with and without chloride ion. The studies reveal that the single methyl violet is not an effective inhibitor for cold rolled steel in sulphuric acid solution, but the complex of methyl violet and chloride ion shows a quite well inhibition. A synergistic effect was observed and discussed. The thermodynamic parameters such as adsorption free energy, adsorption heat and adsorption entropy, kinetic data such as apparent activation energy and pre-exponential factor were calculated and discussed. Potentiodynamic polarization researches show that single methyl violet mainly acts as a cathodic-type inhibitor, however the mixture of methyl violet and sodium chloride acts as a mixed-type inhibitor and shows dominant effect on the cathodic reaction.
\end{abstract}

Key Words: Corrosion, Steel, Sulphuric acid, Methyl violet, Adsorption, Synergistic inhibition.

\section{INTRODUCTION}

The corrosion of steel has received a considerable amount of attentions as a result of its industrial concern. Acid solutions are generally used as for removal of undesirable scale and rust in several industrial processes. Sulphuric acid and hydrochloric acid are widely used in the pickling processes of metal. The use of inhibitor to control the attack of acid solution and protect the corrosion of metal was found to have widespread applications in many industries ${ }^{1,2}$. The inhibition of steel corrosion in acidic solution by different type organic compounds has been widely studied ${ }^{3-7}$. Most of the acid inhibitors are organic compounds containing nitrogen ${ }^{8-14}$, sulphur ${ }^{15-19}$ and oxygen $^{20-24}$ atoms. Some studies indicate that nitrogen-containing organic inhibitors show better inhibition for the steel corrosion in hydrochloric acid than in sulphuric acid ${ }^{25,26}$. The possible reason is that there is a synergistic inhibition between chloride ion and nitrogen-containing organic inhibitors for steel in hydrochloric acid. Some researches about synergism between organic compounds and chloride ion on metal corrosion in acidic solution have been reported ${ }^{14,27-29}$. Synergism is a combined action of compounds and synergistic effects have been frequently used in practice for its efficiency and economy ${ }^{30-33}$.

Methyl violet is an indicator in analytical chemistry. It contains nitrogen atoms unshared electron pairs and abundant $\pi$-electrons heterocyclic, which could transfer the unshared electron pairs to the $d$-orbitals of iron surface atoms. This nitrogen-containing heterocyclic compound should meet the requirements as an inhibitor for the corrosion of steel in acid solution. Little work appears on the methyl violet being used as an acidic inhibitor. In the present work, the synergistic inhibitive effects between methyl violet and chloride ion for the corrosion of steel in sulphuric acid solutions have been studied by weight loss and electrochemical methods.

EXPERIMENTAL

The chemical composition wt $\%$ of cold rolled steel was as follows: $0.05 \% \mathrm{C}, 0.02 \% \mathrm{Si}, 0.21 \% \mathrm{Mn}, 0.21 \% \mathrm{P}, 0.019 \%$ $\mathrm{S}$ and remainder iron. Cold rolled steel pieces of $4 \mathrm{~cm} \times 1.5$ $\mathrm{cm} \times 0.04 \mathrm{~cm}$ were used in the experiments.

All solutions were prepared from bidistilled water and AR grade sulphuric acid and sodium chloride $(\mathrm{NaCl})$ were used. Methyl violet was supplied by Merck Chemicals. Fig. 1 shows the molecular structure of methyl violet.

For polarization tests, the steel specimen was embedded in PVC holder using chemical resistant epoxy resin as a working electrode. The working surface area was $1 \mathrm{~cm}^{2}$. The counter electrode was platinum and the reference was a saturated calomel electrode (SCE) coupled to a Luggin capillary.

General procedure: The specimens for weight loss and polarization measurements were successively abraded with a series of emery paper from 300-1200 grades. They were then 
<smiles>CNC1C=CC(=C(c2ccc(N(C)C)cc2)c2ccc(N(C)C)cc2)C=C1</smiles>

Fig. 1. Structure of methyl violet

washed in bidistilled water, degreased in acetone and dried using a stream of air.

For weight loss studies, the specimens were weighed accurately and immersed in the test solutions for $4 \mathrm{~h}$ in air without bubbling. At the conclusion of a run the specimens were taken out, washed with bidistilled water and acetone, dried and immediately weighed accurately. Then the tests were repeated at different temperatures.

For polarization studies, before measurement the electrode was immersed in test solution at natural potential for $2 \mathrm{~h}$ until a steady state was reached. All polarization curves were recorded by a PARSTAT 2263 Potentiostat/Galvanostat (Princeton Applied Research) at $30{ }^{\circ} \mathrm{C}$. The potential scan rate was 30 $\mathrm{mV} / \mathrm{min}$.

\section{RESULTS AND DISCUSSION}

Weight loss measurements: The inhibition efficiency (IE) of the inhibitor for the corrosion of cold rolled steel was calculated as follows:

$$
\operatorname{IE}(\%)=\left(1-\frac{\mathrm{W}_{\mathrm{i}}}{\mathrm{W}_{\mathrm{u}}}\right) \times 100
$$

where $\mathrm{W}_{\mathrm{i}}$ and $\mathrm{W}_{\mathrm{u}}$ are the weight losses per unit area per unit time in the presence and absence of the inhibitor, respectively. Fig. 2 gives the corrosion rate values of cold rolled steel in 0.5 $\mathrm{mol} / \mathrm{dm}^{3} \mathrm{H}_{2} \mathrm{SO}_{4}$ solution at different concentrations of methyl violet at different temperatures.

The corrosion rates of the steel gradually decrease as the concentration of methyl violet increases at each experimental temperature. It is also obvious that the corrosion rates of the steel increase with an increase in temperature.

The relationship between corrosion rate and concentration of methyl violet in the presence of $0.1 \mathrm{~mol} / \mathrm{dm}^{3} \mathrm{NaCl}$ in 0.5 $\mathrm{mol} / \mathrm{dm}^{3} \mathrm{H}_{2} \mathrm{SO}_{4}$ is given in Fig. 3. Compared with Fig. 2, the corrosion rates of the steel in the presence of $0.1 \mathrm{~mol} / \mathrm{dm}^{3}$ $\mathrm{NaCl}$ drastically decrease as the concentration of methyl violet increases at each experimental temperature and the corrosion rate values do not change basically above $30 \mu \mathrm{mol} / \mathrm{dm}^{3}$ of methyl violet. Even at each experimental temperature the corrosion rates also keep still steady above $30 \mu \mathrm{mol} / \mathrm{dm}^{3}$ of methyl violet.

Table-1 gives the values of inhibition efficiencies of different concentrations of methyl violet in $0.5 \mathrm{~mol} / \mathrm{dm}^{3} \mathrm{H}_{2} \mathrm{SO}_{4}$ in the absence and presence of $0.1 \mathrm{~mol} / \mathrm{dm}^{3} \mathrm{NaCl}$ at different temperatures. As seen, the inhibition efficiency increases with increasing methyl violet concentration from 50 to $100 \mu \mathrm{mol} / \mathrm{dm}^{3}$

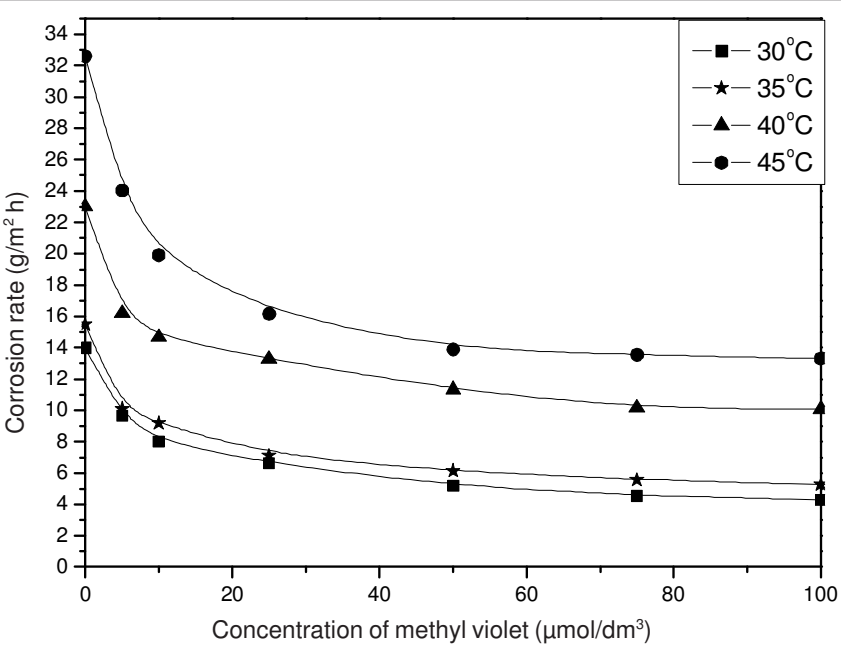

Fig. 2. Variation of corrosion rate of cold rolled steel with concentration of methyl violet in the absence of $\mathrm{NaCl}$ in $0.5 \mathrm{~mol} / \mathrm{dm}^{3} \mathrm{H}_{2} \mathrm{SO}_{4}$

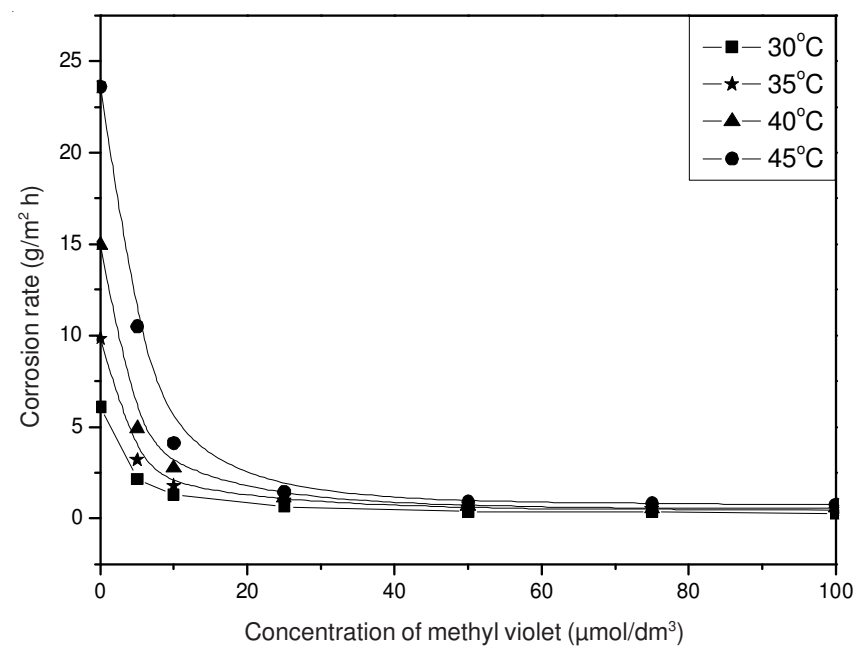

Fig. 3. Variation of corrosion rate of cold rolled steel with concentration of methyl violet in the presence of $0.1 \mathrm{~mol} / \mathrm{dm}^{3} \mathrm{NaCl}$ in $0.5 \mathrm{~mol} /$ $\mathrm{dm}^{3} \mathrm{H}_{2} \mathrm{SO}_{4}$

in the absence of $\mathrm{NaCl}$, while decreases with experimental temperature increased, which means the inhibition of methyl violet for steel corrosion might be caused by the adsorption of methyl violet on the steel surface. The desorption of methyl violet from the steel surface might be taken place at higher temperature. The highest inhibition efficiency is $69 \%$ (at $30^{\circ} \mathrm{C}$ ) and single $\mathrm{NaCl}$ can not show so well inhibition efficiency.

When the $\mathrm{NaCl}$ was added into the $0.5 \mathrm{~mol} / \mathrm{dm}^{3} \mathrm{H}_{2} \mathrm{SO}_{4}$ solutions containing the different concentrations of methyl violet. It is very clear that the inhibition efficiency is quietly improved compared the only in the presence of single methyl violet or $\mathrm{NaCl}$. Even at very low concentration of methyl violet $\left(10 \mu \mathrm{mol} / \mathrm{dm}^{3}\right)$, the inhibition efficiency of the complex (methyl violet and $\mathrm{NaCl}$ ) has reached to $91 \%$ at $30^{\circ} \mathrm{C}$. At other experimental temperatures, the inhibition efficiencies of the complex are all $>90 \%$ at $25 \mu \mathrm{mol} / \mathrm{dm}^{3}$ of methyl violet. It is important that the changes of the experimental temperature and concentration of methyl violet do not influence the values of inhibition efficiency basically. It is worth noting that at higher experimental temperature $\left(40-45^{\circ} \mathrm{C}\right)$ and at $35^{\circ} \mathrm{C}\left(5-25 \mu \mathrm{mol} / \mathrm{dm}^{3}\right.$ of methyl violet), the inhibition efficiencies of the complex 


\begin{tabular}{|c|c|c|c|c|c|}
\hline \multicolumn{6}{|c|}{$\begin{array}{c}\text { TABLE-1 } \\
\text { INHIBITION EFFICIENCIES FOR DIFFERENT } \\
\text { CONCENTRATIONS OF METHYL VIOLET IN } 0.5 \mathrm{~mol} / \mathrm{dm}^{3} \\
\mathrm{H}_{2} \mathrm{SO}_{4} \text { WITH AND WITHOUT ADDITION OF } 0.1 \mathrm{~mol} / \mathrm{dm}^{3} \\
\mathrm{NaCl} \text { AT DIFFERENT TEMPERATURES }\end{array}$} \\
\hline \multirow{2}{*}{$\begin{array}{l}\text { Concentration of } \\
\text { MV }\left(\mu \mathrm{mol} / \mathrm{dm}^{3}\right)\end{array}$} & \multirow{2}{*}{$\begin{array}{c}\mathrm{NaCl} \\
\left(\mathrm{mol} / \mathrm{dm}^{3}\right)\end{array}$} & \multicolumn{4}{|c|}{ Inhibition efficiency (\%) } \\
\hline & & $30^{\circ} \mathrm{C}$ & $35^{\circ} \mathrm{C}$ & $40^{\circ} \mathrm{C}$ & $45^{\circ} \mathrm{C}$ \\
\hline 0 & 0 & - & - & - & - \\
\hline 5 & 0 & 31.1 & 34.4 & 30.0 & 26.2 \\
\hline 10 & 0 & 42.6 & 40.6 & 39.2 & 39.0 \\
\hline 25 & 0 & 52.6 & 54.0 & 44.3 & 44.0 \\
\hline 50 & 0 & 62.9 & 60.4 & 54.8 & 54.4 \\
\hline 75 & 0 & 67.4 & 64.0 & 56.8 & 56.4 \\
\hline 100 & 0 & 69.2 & 66.0 & 58.2 & 57.3 \\
\hline 0 & 0.1 & 56.4 & 36.5 & 35.1 & 24.8 \\
\hline 5 & 0.1 & 84.5 & 79.4 & 78.6 & 66.5 \\
\hline 10 & 0.1 & 90.8 & 88.5 & 88.0 & 86.8 \\
\hline 25 & 0.1 & 95.4 & 93.9 & 95.1 & 95.4 \\
\hline 50 & 0.1 & 97.4 & 96.6 & 97.1 & 97.1 \\
\hline 75 & 0.1 & 97.4 & 96.8 & 97.7 & 97.4 \\
\hline 100 & 0.1 & 98.0 & 97.1 & 97.6 & 97.6 \\
\hline
\end{tabular}

are larger than the summation of the inhibition efficiency of single methyl violet and $\mathrm{NaCl}$ alone, which means that there is a strong synergistic inhibition between methyl violet and $\mathrm{NaCl}$ for the steel corrosion in sulphuric acid solution.

Adsorption isotherm: Assuming the corrosion inhibition was caused by the adsorption of the inhibitor on the steel surface and the Langmuir adsorption isotherm was applied to study the adsorption mechanism ${ }^{34}$ :

$$
\frac{\mathrm{C}}{\theta}=\frac{1}{\mathrm{~K}}+\mathrm{C}
$$

where $\mathrm{C}$ is the concentration of the inhibitor, $\mathrm{K}$ is the adsorptive equilibrium constant $\left(\left(\mathrm{mol} / \mathrm{dm}^{3}\right)^{-1}\right)$ and $\theta$ is the surface coverage. $\theta$ was calculated by the Skeine method ${ }^{35}$ :

$$
\theta=\frac{\left(\mathrm{w}_{\mathrm{u}}-\mathrm{w}\right)}{\left(\mathrm{w}_{\mathrm{u}}-\mathrm{w}_{\mathrm{m}}\right)}
$$

where $\mathrm{w}_{\mathrm{m}}$ is the smallest corrosion rate, $\mathrm{w}_{\mathrm{u}}$ and $\mathrm{w}$ are the corrosion rate without and with addition of inhibitor, respectively.

From the eqn. 2 , the linear regression between $\mathrm{C} / \theta$ and $\mathrm{C}$ were calculated by computer. Fig. 4 gives the relationship between $\mathrm{C} / \theta$ and $\mathrm{C}$ in the absence of $\mathrm{NaCl}$ and the obtained parameters are shown in Table- 2 .

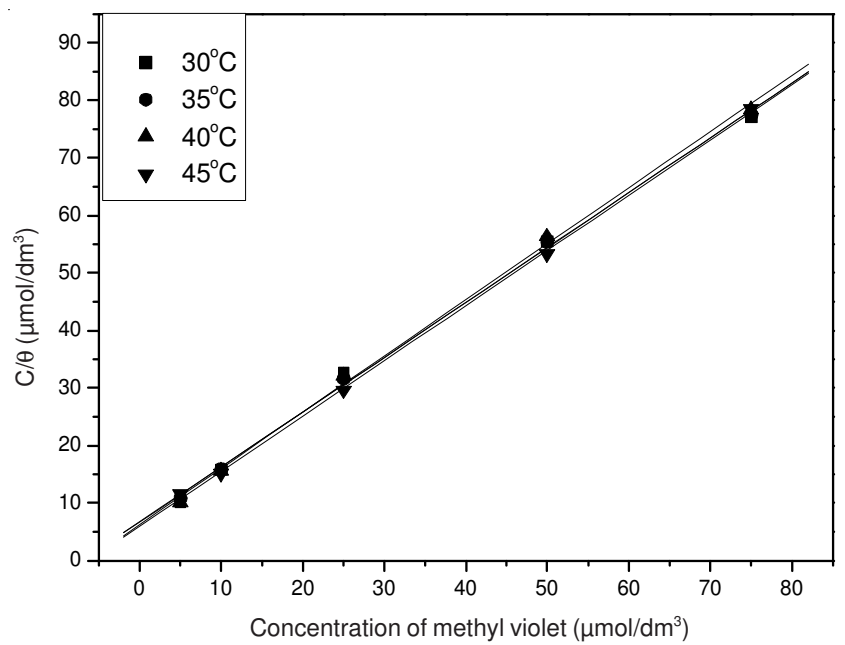

Fig. 4. Relationship between $\mathrm{c} / \theta$ and concentration of methyl violet for steel corrosion in $0.5 \mathrm{~mol} / \mathrm{dm}^{3} \mathrm{H}_{2} \mathrm{SO}_{4}$
TABLE-2

PARAMETERS OF THE LINEAR REGRESSION BETWEEN C/ $\theta$ AND C IN THE ABSENCE OF NaCl

\begin{tabular}{cccc}
\hline $\begin{array}{c}\text { Temperature } \\
\left({ }^{\circ} \mathrm{C}\right)\end{array}$ & $\begin{array}{c}\text { Linear correlation } \\
\text { coefficient }\end{array}$ & Slope & $\begin{array}{c}\mathrm{K} \\
\left(\times 10^{5} \mathrm{dm}^{3} / \mathrm{mol}\right)\end{array}$ \\
\hline 30 & 0.999 & 0.953 & 1.47 \\
35 & 1.000 & 0.954 & 1.48 \\
40 & 0.999 & 0.976 & 1.58 \\
45 & 1.000 & 0.959 & 1.67 \\
\hline
\end{tabular}

The results show that all the linear correlation coefficients are almost close to 1 and all the slopes are very close to 1 , which means that the adsorption of methyl violet on the steel surface in the absence of $\mathrm{NaCl}$ follows the Langmuir adsorption isotherm. From the Table-2, the larger values of the adsorptive equilibrium constant show that it is easily adsorbed strongly onto the steel surface for the inhibitor.

In the presence of $0.1 \mathrm{~mol} / \mathrm{dm}^{3}$ chloride ion, the adsorption of methyl violet on the steel surface also follows the Langmuir adsorption isotherm (Fig. 5 and Table-3).

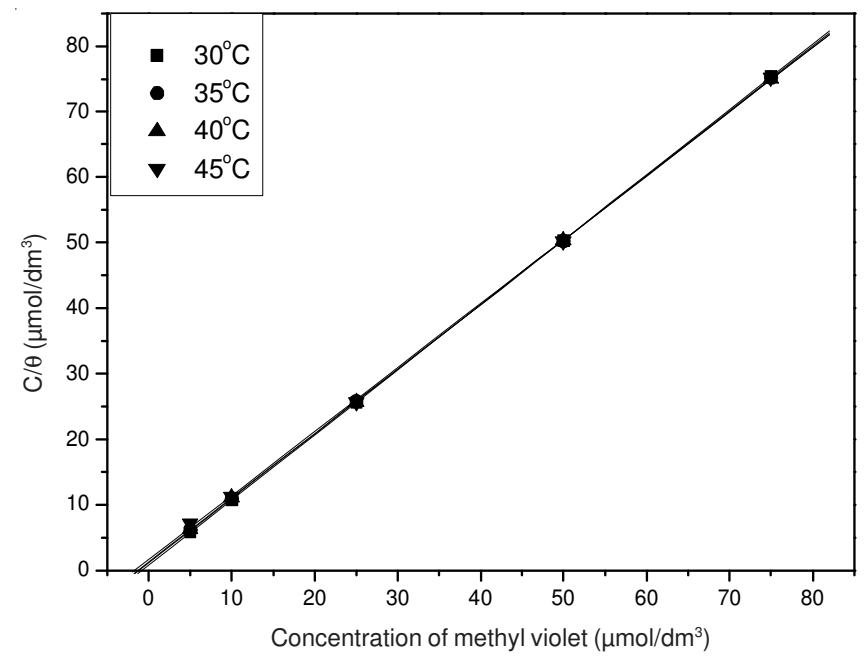

Fig. 5. Relationship between $\mathrm{C} / \theta$ and concentration of methyl violet for steel corrosion in $0.5 \mathrm{~mol} / \mathrm{dm}^{3} \mathrm{H}_{2} \mathrm{SO}$ in the presence of $0.1 \mathrm{~mol} /$ $\mathrm{dm}^{3} \mathrm{NaCl}$

TABLE-3

PARAMETERS OF THE LINEAR REGRESSION BETWEEN C/ $\theta$ AND C IN THE PRESENCE OF $0.1 \mathrm{~mol} / \mathrm{dm}^{3} \mathrm{NaCl}$

\begin{tabular}{cccc}
\hline $\begin{array}{c}\text { Temperature } \\
\left({ }^{\circ} \mathrm{C}\right)\end{array}$ & $\begin{array}{c}\text { Linear correlation } \\
\text { coefficient }\end{array}$ & Slope & $\begin{array}{c}\mathrm{K} \\
\left(\times 10^{5} \mathrm{dm}^{3} / \mathrm{mol}\right)\end{array}$ \\
\hline 30 & 1.000 & 0.994 & 13.0 \\
35 & 1.000 & 0.987 & 8.94 \\
40 & 1.000 & 0.983 & 8.17 \\
45 & 1.000 & 0.977 & 6.09 \\
\hline
\end{tabular}

Compared the values of $\mathrm{K}$ between in the presence and absence of chloride ion, it is found that the values of $\mathrm{K}$ are larger in the presence of chloride ion than absence. The synergistic inhibition is clear.

Thermodynamic parameters: The adsorption heat could be calculated according to the van't Hoff equation ${ }^{34}$ :

$$
\ln \mathrm{K}=\frac{\left(-\Delta \mathrm{H}_{\mathrm{ads}}\right)}{\mathrm{RT}}+\text { constant }
$$

where $\Delta \mathrm{H}_{\mathrm{ads}}$ is the adsorption heat $\mathrm{T}$ is the absolute temperature. 
The relationships between $\ln \mathrm{K}$ and $1 / \mathrm{T}$ in the absence and presence of $0.1 \mathrm{~mol} / \mathrm{dm}^{3}$ chloride ion are shown in Figs. 6 and 7 , respectively.

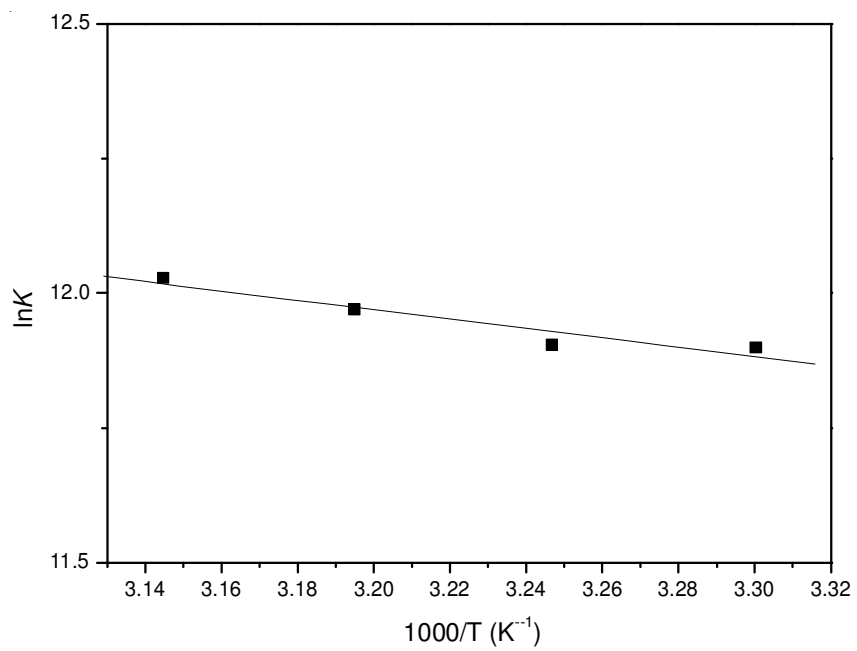

Fig. 6. Relationship between $\ln \mathrm{K}$ and $1 / \mathrm{T}$ in the absence of $\mathrm{NaCl}$

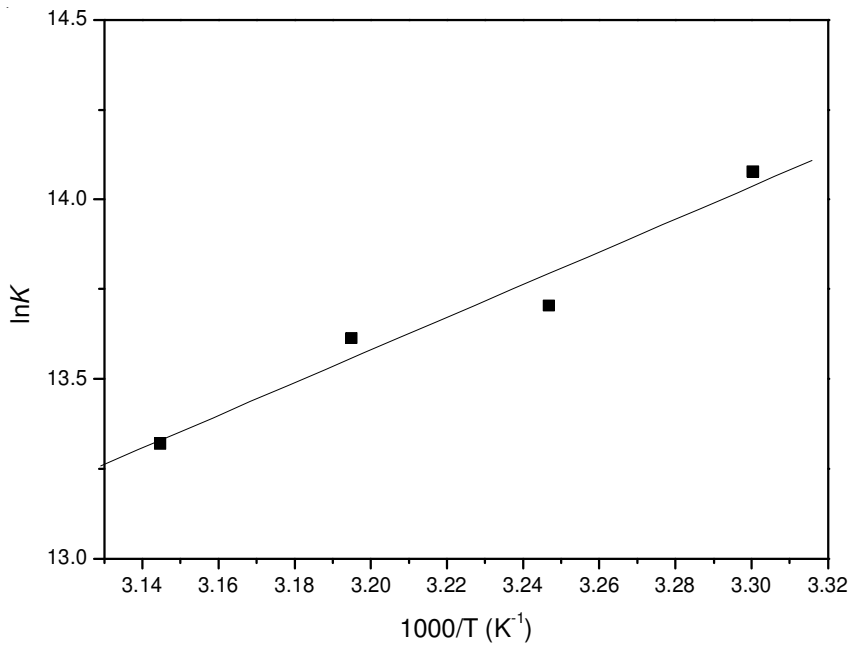

Fig. 7. Relationship between $\ln \mathrm{K}$ and $1 / \mathrm{T}$ in the presence of $0.1 \mathrm{~mol} / \mathrm{dm}^{3}$ $\mathrm{NaCl}$

To obtain the standard adsorption free energy $\left(\Delta \mathrm{G}_{\mathrm{ads}}\right)$, the following equation was used ${ }^{36,37}$ :

$$
\mathrm{K}=\left(\frac{1}{55.5}\right) \exp \left(\frac{-\Delta \mathrm{G}_{\mathrm{ads}}}{\mathrm{RT}}\right)
$$

So the standard adsorption entropy $\left(\Delta \mathrm{S}_{\mathrm{ads}}\right)$ could be calculated by the thermodynamic basic equation:

$$
\Delta \mathrm{G}_{\mathrm{ads}}=\Delta \mathrm{H}_{\mathrm{ads}}-\mathrm{T} \Delta \mathrm{S}_{\mathrm{ads}}
$$

Table- 4 gives the calculated thermodynamic parameters. Without addition of $0.1 \mathrm{~mol} / \mathrm{dm}^{-3}$ chloride ion, the positive values of $\Delta \mathrm{H}_{\text {ads }}$ suggest that the adsorption of methyl violet is an endothermic process. In the presence of $0.1 \mathrm{~mol} / \mathrm{dm}^{3}$ chloride ion the values of $\Delta \mathrm{H}_{\mathrm{ads}}$ are negative, which indicates that the adsorption of the inhibitors (methyl violet and $\mathrm{Cl}^{-}$) is an exothermic process.

The negative values of $\Delta \mathrm{G}_{\mathrm{ads}}$ indicate that the adsorption of the inhibitor on the steel surface is a spontaneous process. Generally, values of $\Delta \mathrm{G}_{\mathrm{ads}}$ around $20 \mathrm{~kJ} / \mathrm{mol}$ or lower are
TABLE-4

THERMODYNAMIC PARAMETERS FOR ADSORPTION OF METHYL VIOLET ON THE COLD ROLLED STEEL SURFACE AT DIFFERENT TEMPERATURES

\begin{tabular}{ccccc}
\hline $\begin{array}{c}\text { Temperature } \\
\left({ }^{\circ} \mathrm{C}\right)\end{array}$ & $\begin{array}{c}\mathrm{NaCl} \\
\left(\mathrm{mol} / \mathrm{dm}^{3}\right)\end{array}$ & $\begin{array}{c}\Delta \mathrm{G}_{\mathrm{ads}} \\
(\mathrm{kJ} / \mathrm{mol})\end{array}$ & $\begin{array}{c}\Delta \mathrm{H}_{\mathrm{ads}} \\
(\mathrm{kJ} / \mathrm{mol})\end{array}$ & $\begin{array}{c}\Delta \mathrm{S}_{\mathrm{ads}} \\
(\mathrm{J} / \mathrm{mol} \mathrm{K})\end{array}$ \\
\hline 30 & 0 & -40.1 & 7.23 & 156 \\
35 & 0 & -40.8 & 7.23 & 156 \\
40 & 0 & -41.6 & 7.23 & 156 \\
45 & 0 & -42.4 & 7.23 & 156 \\
30 & 0.1 & -45.6 & -37.9 & 25.4 \\
35 & 0.1 & -45.4 & -37.9 & 24.4 \\
40 & 0.1 & -45.9 & -37.9 & 25.6 \\
45 & 0.1 & -45.8 & -37.9 & 24.8 \\
\hline
\end{tabular}

consistent with the electrostatic interaction between the charged molecules and the charged metal (physisorption), while those more negative than $-40 \mathrm{~kJ} / \mathrm{mol}$ involve charge sharing or transfer from the inhibitor molecules to the metal surface to form a coordinate type of bond (chemisorption) ${ }^{38,39}$. The values of $\Delta \mathrm{G}_{\text {ads }}$ for methyl violet in the presence or absence of chloride ion being more negative than $40 \mathrm{~kJ} / \mathrm{mol}$ means that the adsorption mechanism of the methyl violet on the steel surface in $0.5 \mathrm{~mol} / \mathrm{dm}^{3} \mathrm{H}_{2} \mathrm{SO}_{4}$ solution is chemisorption, which suggests the transference of electrons from nitrogen atoms of methyl violet to the $d$-orbitals of the iron surface atoms.

The sign of $\Delta \mathrm{S}_{\text {ads }}$ is positive, which could be explained as follows: The adsorption of organic inhibitor molecules from the aqueous solution can be regard as a quasi-substitution process between the organic molecules in the aqueous phase and water molecules at the electrode surface ${ }^{40}$. The adsorption of methyl violet is accompanied by desorption of water molecules from the surface. So, while the adsorption process of the inhibitor is believed to be exothermic and associated with a decrease in entropy of the solute, the result is opposite for the solvent. The thermodynamic values obtained are the algebraic sum of the adsorption of the inhibitor molecules and the desorption of water molecules and consequently the gain in entropy is attributed to the increase in solvent entropy ${ }^{41,42}$. The driving force for the spontaneous adsorption of methyl violet onto the steel surface is the increase in entropy as well as the decrease in enthalpy.

Kinetic parameters: For the acid corrosion of steel, the logarithm of corrosion rate ( $r$ ) could be represented as a linear function of $1 / \mathrm{T}^{43}$ :

$$
\ln \mathrm{r}=\frac{-\mathrm{E}_{\mathrm{a}}}{\mathrm{RT}}+\ln \mathrm{A}
$$

where $\mathrm{E}_{\mathrm{a}}$ is the apparent activation energy, $\mathrm{R}$ is the gas constant $(8.314 \mathrm{~J} / \mathrm{K} \mathrm{mol})$ and $\mathrm{A}$ is the pre-exponential factor.

Eqn. 7 is shown graphically in Fig. 8. $\mathrm{E}_{\mathrm{a}}$ and $\mathrm{A}$ at different concentrations of methyl violet were calculated by linear regression between $\ln \mathrm{r}$ and $1 / \mathrm{T}$ and the results are given in Table-5. The apparent activation energy acts as a function of concentration of methyl violet from the Table-5. At lower concentration of methyl violet there is the larger value of $E_{a}$. But at higher concentration of methyl violet, the apparent activation energy is smaller than that of the blank. For preexponential factor there is a similar variation.

According to eqn. 7, it can be seen that the rate of steel corrosion is decided by the apparent activation energy and 


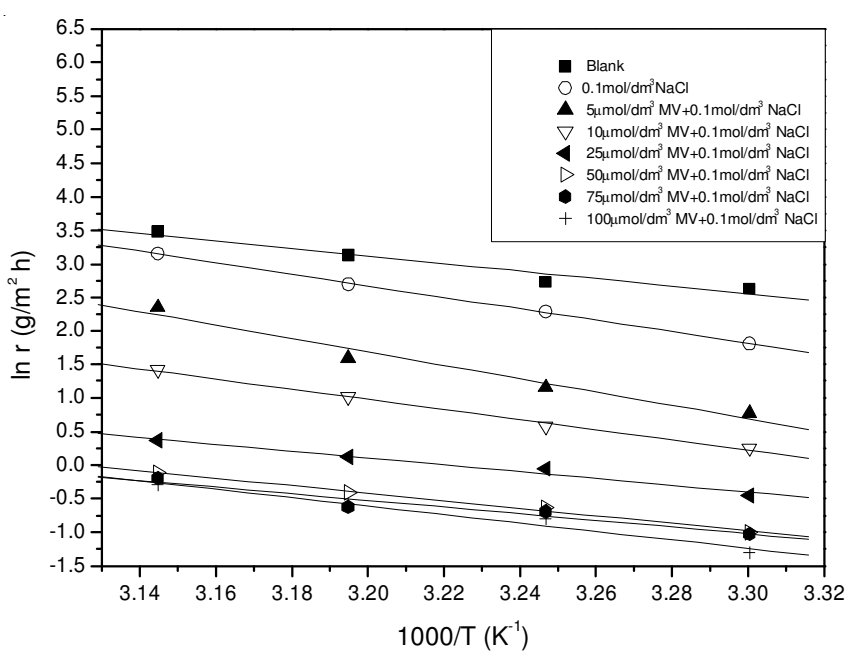

Fig. 8. Arrhenius plots of $\ln \mathrm{r}$ versus $1 / \mathrm{T}$ at different concentrations of methyl violet containing $0.1 \mathrm{~mol} / \mathrm{dm}^{3} \mathrm{NaCl}$ in $0.5 \mathrm{~mol} / \mathrm{dm}^{3} \mathrm{H}_{2} \mathrm{SO}_{4}$

TABLE-5

PARAMETERS OF THE REGRESSION BETWEEN $\ln \mathrm{r}$ AND 1/T

\begin{tabular}{ccccc}
\hline $\begin{array}{c}\text { Conc. of } \\
\text { methyl violet } \\
\left(\mu \mathrm{mol} / \mathrm{dm}^{3}\right)\end{array}$ & $\begin{array}{c}\mathrm{NaCl} \\
\left(\mathrm{mol} / \mathrm{dm}^{3}\right)\end{array}$ & $\begin{array}{c}\mathrm{E}_{\mathrm{a}} \\
(\mathrm{kJ} / \mathrm{mol})\end{array}$ & $\begin{array}{c}\text { Pre- } \\
\text { exponential } \\
\text { factor }\left(\mathrm{g} / \mathrm{m}^{2} \mathrm{~h}\right)\end{array}$ & $\begin{array}{c}\text { Linear } \\
\text { regression } \\
\text { coefficient }\end{array}$ \\
\hline 0 & 0.0 & 46.9 & $1.58 \times 10^{8}$ & 0.974 \\
0 & 0.1 & 71.8 & $1.46 \times 10^{13}$ & 1.000 \\
5 & 0.1 & 82.7 & $3.59 \times 10^{14}$ & 0.984 \\
10 & 0.1 & 62.9 & $8.61 \times 10^{10}$ & 0.999 \\
25 & 0.1 & 45.8 & $8.32 \times 10^{7}$ & 0.988 \\
50 & 0.1 & 44.3 & $3.40 \times 10^{7}$ & 0.996 \\
75 & 0.1 & 41.1 & $4.31 \times 10^{6}$ & 0.968 \\
100 & 0.1 & 43.7 & $1.13 \times 10^{7}$ & 0.986 \\
\hline
\end{tabular}

pre-exponential factor at a certain temperature. When the concentration of methyl violet is from $5-10 \mu \mathrm{mol} / \mathrm{dm}^{3}$, the reduction in the steel corrosion rate is mostly decided by the increase of the apparent activation energy. However in the concentration of methyl violet between $25-100 \mu \mathrm{mol} / \mathrm{dm}^{3}$, the decrease of steel corrosion rate is mainly decided by decreasing the value of pre-exponential factor.

According to the relationship of the apparent activation energy with concentration of methyl violet, it is seen that there is a "peak" value of the apparent activation energy, which is similar to the literature ${ }^{14}$.

Polarization measurements: Fig. 9 shows the potentiodynamic polarization curves obtained for cold rolled steel in $0.5 \mathrm{~mol} / \mathrm{dm}^{3}$ sulphuric acid solution without and with different concentration of the inhibitors at $30^{\circ} \mathrm{C}$.

The inhibition efficiency (IE) was calculated from the following equation:

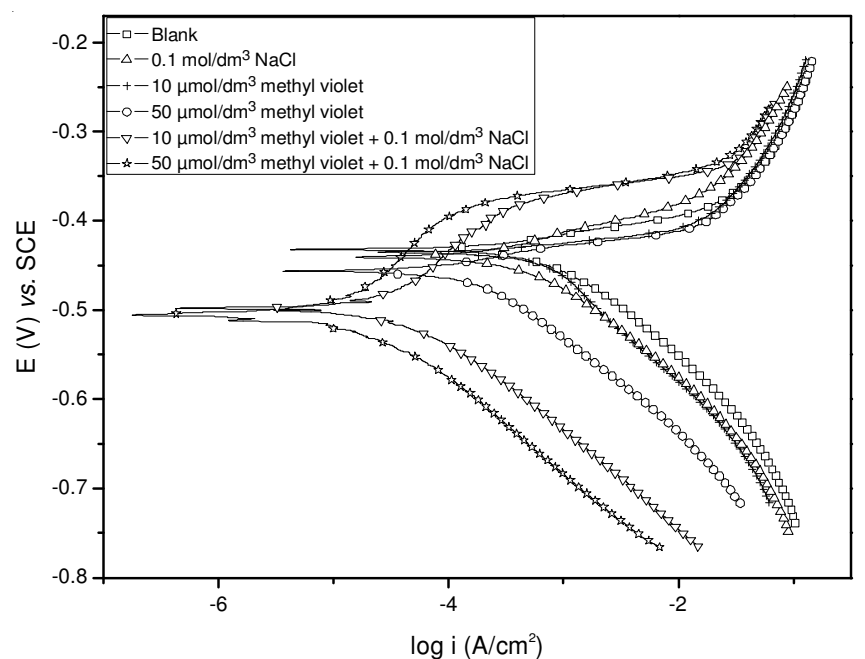

Fig. 9. Polarization curves for cold rolled steel in $0.5 \mathrm{~mol} / \mathrm{dm}^{3} \mathrm{H}_{2} \mathrm{SO}_{4}$ in the absence and presence of various concentrations of inhibitors at $30^{\circ} \mathrm{C}$

$$
\operatorname{IE}(\%)=\left(\frac{\mathrm{i}_{\text {corr }}^{0}-\mathrm{i}_{\text {corr }}}{\mathrm{i}_{\text {corr }}^{0}}\right) \times 100
$$

where $i_{\text {corr }}^{0}$ and $i_{\text {corr }}$ are the corrosion current densities in the absence and presence of the inhibitor, respectively.

Table- 6 shows the electrochemical parameters such as corrosion potential $\left(\mathrm{E}_{\text {corr }}\right)$, corrosion current density $\left(\mathrm{i}_{\text {corr }}\right)$, Tafel slopes $\left(\beta_{\mathrm{a}}, \beta_{\mathrm{c}}\right)$ calculated by using Tafel fit and inhibition efficiency.

It is seen that the anodic and cathodic corrosion reactions are slightly inhibited by the single $0.1 \mathrm{~mol} / \mathrm{dm}^{3} \mathrm{NaCl}$. It is clear that the single methyl violet inhibits the cathodic corrosion reaction and has a larger inhibition action at a higher concentration of methyl violet. At same time the single methyl violet also shows a slight acceleration for anodic corrosion reaction.

When the methyl violet and $0.1 \mathrm{~mol} / \mathrm{dm}^{3} \mathrm{NaCl}$ are present together, it is very apparent that both cathodic and anodic corrosion reactions are greatly inhibited, especially cathodic curves shifted notably, which indicates that methyl violet and $\mathrm{NaCl}$ show a strong synergistic inhibition for the steel corrosion in $0.5 \mathrm{~mol} / \mathrm{dm}^{3}$ sulphuric acid solution. From the polarization curves, the complex formation of methyl violet and $\mathrm{NaCl}$ shifts $\mathrm{E}_{\text {corr }}$ in the negative direction and acts as a mixed-type inhibitor but cathodic polarization is dominant for the corrosion of cold rolled steel in $0.5 \mathrm{~mol} / \mathrm{dm}^{3}$ sulphuric acid solution.

It is found that all the anodic and cathodic Tafel slopes change, especially in the presence of methyl violet and $\mathrm{NaCl}$, which may be suggest that the mixture of methyl violet and

\begin{tabular}{ccccccc}
\multicolumn{7}{c}{ TABLE-6 } \\
\multicolumn{7}{c}{$\begin{array}{l}\text { ELECTROCHEMICAL PARAMETERS OBTAINED FROM TAFEL } \\
\text { POLARIZATION MEASUREMENTS FOR COLD ROLLED STEEL AT 30 }\end{array}{ }^{\circ} \mathrm{C}$} \\
\hline $\begin{array}{c}\text { Concentration of methyl } \\
\text { violet }\left(\mu \mathrm{mol} / \mathrm{dm}^{3}\right)\end{array}$ & $\begin{array}{c}\mathrm{NaCl} \\
\left(\mathrm{mol} / \mathrm{dm}^{3}\right)\end{array}$ & $\begin{array}{c}\mathrm{E}_{\text {corr }} \\
(\mathrm{mV})\end{array}$ & $\begin{array}{c}\mathrm{i}_{\text {corr }} \\
\left(\mu \mathrm{A} / \mathrm{cm}^{2}\right)\end{array}$ & $\begin{array}{c}\beta_{\mathrm{c}} \\
(\mathrm{mV} / \mathrm{dec})\end{array}$ & $\begin{array}{c}\beta_{\mathrm{a}} \\
(\mathrm{mV} / \mathrm{dec})\end{array}$ & $\begin{array}{c}\mathrm{IE} \\
(\%)\end{array}$ \\
\hline 0 & 0 & -431.2 & 698.2 & 109.01 & 39.18 & - \\
0 & 0.1 & -439.9 & 339.9 & 92.42 & 34.49 & 51.3 \\
10 & 0 & -435.2 & 474.0 & 92.47 & 19.10 & 32.1 \\
50 & 0 & -456.1 & 191.3 & 103.14 & 46.54 & 72.6 \\
10 & 0.1 & -498.7 & 37.13 & 86.94 & 128.76 & 94.7 \\
50 & 0.1 & -504.7 & 9.48 & 75.27 & 101.78 & 98.6 \\
\hline
\end{tabular}


$\mathrm{NaCl}$ affects the mechanism of the anodic and cathodic reaction. The corrosion current decreases with increasing concentration of methyl violet, while the reduction of the corrosion current is more distinct with the addition of $0.1 \mathrm{~mol} / \mathrm{dm}^{3} \mathrm{NaCl}$, meaning the existence of synergistic inhibition between methyl violet and chloride ion for the steel corrosion in 0.5 $\mathrm{mol} / \mathrm{dm}^{3}$ sulphuric acid solution. As presented in Table-6, it is clear that in the presence of $0.1 \mathrm{~mol} / \mathrm{dm}^{3} \mathrm{NaCl}$, the inhibition efficiency increases with increasing the concentration of methyl violet, which is similar to that obtained from weight loss tests.

Mechanism of synergistic inhibition: When methyl violet is dissolved in acid solution protonation can occur as following:

$$
\mathrm{MaV}+\mathrm{xH}^{+} \rightarrow\left[\mathrm{MaVH}_{\mathrm{x}}\right]^{\mathrm{x}}
$$

It is known that steel surface contains positive charge in the acid solution, so the negatively charged chloride ion would attach to positively charged surface of steel ${ }^{44}$. However it is difficult that the protonated methyl violet attach directly to the positively charged surface of steel due to the electrostatic repulsion, which explains the reason that single methyl violet could not show an excellent inhibition for the steel corrosion in sulphuric acid solution. When methyl violet and chloride ion exist commonly in acid solution, the negatively charged chloride ion could attach to the steel surface charged positively, then the protonated methyl violet could reach to the steel surface easily because of the electrostatic interaction between protonated methyl violet and chloride ion. Afterwards the donor-acceptor interaction between the nitrogen atom or $\pi$-electrons of methyl violet and the vacant $d$-orbitals of iron surface atoms could occur ${ }^{45}$. In this system both physical and chemical adsorption might happen and chloride ion plays a role like a bridge.

\section{Conclusion}

Single methyl violet could not show satisfactory inhibition efficiency for steel corrosion in sulphuric acid, but in the presence of $0.1 \mathrm{~mol} / \mathrm{dm}^{3} \mathrm{NaCl}$, the inhibition efficiency of methyl violet is enormously increased. Even at $10 \mu \mathrm{mol} / \mathrm{dm}^{3}$, the inhibition efficiency has reached to $91 \%$ at $30{ }^{\circ} \mathrm{C}$, which indicates that there is a synergistic inhibition between methyl violet and chloride ion for the steel corrosion in sulphuric acid solution. The adsorptions of methyl violet on the cold rolled steel surface in the absence and presence of $\mathrm{NaCl}$ obeys the Langmuir adsorption isotherm. The adsorption process is a spontaneous process accompanied by an increase in entropy. The adsorption mechanism of the methyl violet on the steel surface is chemisorption. Single methyl violet mainly acts as a cathodic-type inhibitor for steel corrosion in $0.5 \mathrm{~mol} / \mathrm{dm}^{3}$ sulphuric acid solution, while the mixture of methyl violet and $\mathrm{NaCl}$ acts as a mixed-type inhibitor and shows dominant effect on the cathodic reaction. The results from the polarization curves are in good agreement with those of weight loss.

\section{REFERENCES}

1. I.B. Obot and N.O. Obi-Egbedi, Corros. Sci., 52, 1981 (2010).

2. A. Lalitha, S. Ramesh and S. Rajeswari, Electrochim. Acta, 51, 47 (2005).

3. A.O. Yüce and G. Kardas, Corros. Sci., 58, 86 (2012).

4. T. Tüken, F. Demir, N. Kicir, G. Sipircik and M. Erbil, Corros. Sci., 59, 110 (2012).

5. N.A. Negm, M.F. Zaki, M.M. Said and S.M. Morsy, Corros. Sci., 53, 4233 (2011).

6. M.M. Solomon, S.A. Umoren, I.I. Udosoro and A.P. Udoh, Corros. Sci., 52, 1317 (2010).

7. A.Y. Musa, A.A.H. Kadhum, M.S. Takriff, A.R. Daud, S.K. Kamarudin and N. Muhamad, Corros. Eng. Sci. Technol., 45, 163 (2010).

8. N.S. Ayati, S. Khandandel, M. Momeni, M.H. Moayed, A. Davoodi and M. Rahimizadeh, Mater. Chem. Phys., 126, 873 (2011).

9. L. Herrag, B. Hammouti, S. Elkadiri, A. Aouniti, C. Jama, H. Vezin and F. Bentiss, Corros. Sci., 52, 3042 (2010).

10. A.K. Singh and M.A. Quaaishi, Mater. Chem. Phys., 123, 666 (2010).

11. J. Alijourani, K. Raeissi and M.A. Golozar, Corros. Sci., 51, 1836 (2009).

12. T. Kosec, I. Milošev and B. Pihlar, Appl. Surf. Sci., 253, 8863 (2007).

13. L. Wang, Corros. Sci., 48, 608 (2006).

14. L. Tang, X. Li, G. Mu and L. Li, Appl. Surf. Sci., 252, 6394 (2006).

15. X. Li, S. Deng and H. Fu, Corros. Sci., 55, 280 (2012).

16. A. Kosari, M. Momeni, R. Parvizi, M. Zakeri, M.H. Moayed, A. Davoodi and H. Eshghi, Corros. Sci., 53, 3058 (2011).

17. S.M.A. Hosseini and A. Azimi, Corros. Sci., 51, 728 (2009).

18. R. Solmaz, G. Kardas, M. Culha, B. Yazici and M. Erbil, Electrochim. Acta, 53, 5941 (2008)

19. L. Wang, J.X. Pu and H.C. Luo, Corros. Sci., 45, 677 (2003).

20. A.Y. Musa, A.A .h. Kadhum, A.B. Mohamad, A.Z. Daud, M.S. Takriff and S.K. Kamarudin, Corros. Sci., 51, 2393 (2009).

21. A. Yurt, S. Ulutas and H. Dal, Appl. Surf. Sci., 253, 919 (2006).

22. G. Mu and X. Li, J. Colloid Interf. Sci., 289, 184 (2005).

23. M. Gojic, Corros. Sci., 43, 919 (2001).

24. S.S. Abd El Rekim, A.M. Magdy Ibrahim and K.F. Khalid, Mater. Chem. Phys., 70, 268 (2001)

25. F. Bentiss, M. Traisnel, N. Chaibi, B. Mernari, H. Vezin and M. Lagrenëe, Corros. Sci., 44, 2271 (2002).

26. M. Lagrenëe, B. Mernari, M. Bouanis, M. Traisnel and F. Bentiss, Corros. Sci., 44, 573 ( 2002).

27. E.E. Ebenso, Mater. Chem. Phys., 79, 58 (2003)

28. F. Bentiss, M. Bouanis, B. Mernari, M. Traisnel and M. Lagrenëe, $J$. Appl. Electrochem., 32, 671 (2002).

29. T. Du, J. Chen and D. Cao, Br. Corros. J., 35, 229 (2000).

30. H. Amar, J. Benzakour, A. Derja, D. Villemin, B. Moreau, T. Braisaz and A. Tounsi, Corros. Sci., 50, 124 (2008).

31. L. Qiu, Y. Wu, Y. Wang and X. Jiang, Corros. Sci., 50, 576 (2008).

32. L. Tang, X. Li, G. Mu, L. Li and G. Liu, Appl. Surf. Sci., 253, 2367 (2006).

33. L. Tang, X. Li, L. Li, G. Mu and G. Liu, Mater. Chem. Phys., 97, 301 (2006).

34. G. Mu, T. Zhao, M. Liu and T. Gu, Corrosion, 52, 853 (1996).

35. I. Sekine, Y. Hirakawa, Corrosion, 42, 272 (1986).

36. E. Khamis, Corrosion, 46, 476 (1990).

37. M.S. Abdel-aal and M.S. Morad, Br. Corros. J., 36, 253 (2001).

38. F.M. Donahue and K. Nobe, J. Electrochem. Soc., 112, 886 (1965).

39. G. Moretti, F. Guidi and G. Grion, Corros. Sci., 46, 387 (2004).

40. G. Moretti, G. Quartarone, A. Tassan and A. Zingales, Werkst. Korros. (Mater. Corros.), 45, 641 (1994).

41. Emaranuzzaman, T. Kumar, S. Vishwanatham and G. Udayabhanu, Corros. Eng. Sci. Technol., 39, 327 (2004).

42. B. Ateya, B. El-Anadauli and F. El. Nizamy, Corros. Sci., 24, 509 (1984).

43. E.S. Ferreira, C. Giacomelli, F.C. Giacomelli and A. Spinelli, Mater. Chem. Phys., 83, 129 (2004).

44. H. Luo, Y.C. Guan and K.N. Han, Corrosion, 54, 721 (1998).

45. N. Hackerman, E. Snavely Jr. and J.S. Payne Jr., J. Appl. Electrochem., 113, 677 (1966). 